\title{
EDITORIAL
}

\section{A ENFERMAGEM E AS SITUAÇOES DE CRISE}

Nos momentos de crise ou depressão econômica, as organizações, incluindo as de saúde, têm operacionalizado estratégias diversificadas de trabalho, de acordo com a sua filosofia, os scus objetivos, os recursos disponiveis c, principalmente, com o nivel de maturidade do seu pessoal, entendendo-se por maturidade a competência $\mathrm{c}$ a disposição para o trabalho.

Assim, $\propto$ periodos de crise podem representar para os coordenadores de equipes, um desafio para a descoberta de oportunidades construtivas (alto nível de maturidade), como também um fo.tor desencadeante àc comportamento emocionais imediatistas e negativistas (baixo nivel de maturidade).

A história mostra que, nos contextos de crise, como nos periodos de grandes guerras, as organizaçōes têm implementado estratégias de interação do seu pessoal, que possibilitam a sua sobrevivência e posterior fortalecimento.

O Brasil vive, atualmente, uma situação de crise sócio-politica-econômica, que repencute diretamente nas instituições de saúde, com consequiências sérias na qualidade da assistência que está sendo prestada à sociedade.

A Enfermagem, nessas iustituições, em decorrência dessa crise, vê sua prática ceteriorar-se, aumentando a insatisfação e a desmotivação de seus profissionais, agravando a problemática que já é tão complexa.

E o momento, portinto, das enfermeiras responsáveis pela coordenação de equipes, operacionalizarem estratégies para otimização de seus recursos huminos.

Em primeira instância, faz-se necessária a rediscussão das crenças, valores e convicções que estão norteando as açōes dos Serviços de Enfermagem. Esse processo reflexivo deve:á ser realizado com todos os elementos da equipe de enfermagem, para assim haver uma tomada de consciência quanto aos objetivos e estratégias i serem traçadas. 
Após a tomada de decisōes relativas às novas diretrizes a serem implementadas, deve-se investir na capacitação dos recursos humanos, para que os funcionários possam adquirir a competência necessária, para a prestação de uma assistência eficaz.

E necessário, também, que a enfermagem tenha participação nos processos decisórios das instituições, o que permite o desenvolvimento de suas estratégias, na tentativa de mirimizar, então, os efeitos da crise vigente.

Kátia de Carvalho CUNHA

Maria Madalena Januário LEITE

Maria Cristina Komatsu Braga MASSAROLLO 